\title{
Experimental Infections with Cooperia oncophora in Calves
}

\section{A Study with Two Different Larval Dose Levels and Dosing Regimens}

\author{
By F. Satrija and P. Nansen
}

Section of Parasitology, Department of Veterinary Microbiology, Royal Veterinary and Agricultural University, Frederiksberg, Denmark.

\begin{abstract}
Satrija, F. and P. Nansen: Experimental infections with Cooperia oncophora in calves: A study with two different larval dose levels and dosing regimens. Acta vet scand. 1992, 33, 229-236. - The effect of different larval dose levels and dosing regimens on the course of Cooperia oncophora infection in calves was studied. Four groups each of 4 calves were experimentally infected either with 50,000 or 200,000 C. oncophora larvae (L3) given either as single infections or as daily trickle infections. An additional group of calves remained as uninfected controls. The animals were necropsied on week 4 after infection.

Mild to moderate clinical signs of parasitic gastroenteritis developed among calves given high doses of larvae, but liveweight gains were not significantly different from those of the uninfected controls. Serum pepsinogen levels of dosed animals were within normal ranges but rose slightly, and on day 14 p.i. they differed significantly from those of the controls. On that occasion, the levels of serum pepsinogen in the trickle infected groups significantly exhibited the levels of the single infected groups. Hypoalbuminaemia was not a feature on any occasion.

The various groups did not differ significantly with regard to total worm counts and adult worm counts, but the groups receiving high larval doses harboured significantly more fourth stage larvae than the group receiving low doses of larvae, both in terms of absolute counts and in terms of percentages of total worm burdens. Within the same dose level, there was a tendency of a more even distribution of worms along the small intestine when the infection was given as a single infection compared with a trickle infection.

The results indicate that $C$. oncophora larval dose and dosing regimens may influence the pathogenic effects and to some extent the distribution of the parasite in the small intestine.
\end{abstract}

cattle; larval dosing regimen; larval dose size.

\author{
Introduction \\ Cooperia oncophora, which usually occurs in \\ natural concurrent infection with Ostertagia \\ ostertagi, is one of the most prevalent gas- \\ trointestinal worms of cattle in North-West \\ Europe. $O$. ostertagi has been thoroughly
}

studied due to its highly pathogenic effects in first season grazing calves, but there is relatively little information available on the effects of $C$. oncophora on animal production. Some studies indicate that heavy experimental infections with $C$. oncophora may produce 
mild to moderate clinical signs in the form of diarrhoea, hypoalbuminemia, inappetence and weight loss (Coop et al. 1979, Herlich 1965, Henriksen 1981, Armour et al. 1987). Most of the experiments, however, have been carried out on the basis of experimental infections with $\mathrm{C}$. oncophora larvae given as 1 single dose. The present study of $C$. oncophora was designed to determine to which extent differences in larval intake and dosing regimens may influence the course of infection and worm establishment in parasite naive calves.

\section{Materials and methods \\ Experimental design}

The experiment was conducted at the Royal Veterinary and Agricultural University's research farm in Tåstrup situated on Zealand, Denmark. The calves used in the experiment were reared indoors to exclude transmission of parasites. Four groups of calves (groups 2 5) were infected artificially with $C$. oncopho$r a$, and another group (group 1) comprised parasite-free controls. The larvae were given at doses of 50,000 or 200,000 larvae per animal, either as single, or as trickle infections over 10 days (Table 1). Blood and faecal samples from all calves were obtained at 1 week intervals. The calves were slaughtered on week 4 post infection (p.i.).

\section{Experimental animals}

Twenty castrated, male Jersey calves, not previously exposed to trichostrongyle infection as judged from faecal egg counts, were used. The average age and weight at the start of the experiment were 3 months and $121 \mathrm{~kg}$, respectively. The calves were fed with hay ad libitum, and twice daily, concentrate was provided. Five groups each of 4 calves were formed on the basis of body weight.

\section{Infective materials}

The larvae used in the present experiment were cultured from faeces of a donor calf with a monospecific infection of $C$. oncophora, and they were extracted from the culture by means of a modified Baermann apparatus and subsequently stored in ion-free water at $15^{\circ} \mathrm{C}$ until use. Individual larvae doses were administered in gelatine capsules (size 000; TAAB Laboratories, Ltd.) using a polytene tube dosing device.

\section{Laboratory analyses}

Trichostrongyle eggs in faeces were counted using a modified McMaster procedure (Henriksen \& Aagaard 1976). Serum pepsinogen levels were determined according to the procedure described by Ross et al. (1967). Serum albumin levels were determined according to Nisbet et al. (1973).

Post mortem worm counts were performed in the following way: After necropsy the small

Table 1. Experimental design. Dosing scheme for the 5 experimental groups of calves.

\begin{tabular}{ccl}
\hline Group & Number of & Dosing scheme \\
\hline 1 & 4 & Nil \\
2 & 4 & $50,000 \mathrm{~L}_{3}$ C. oncophora \\
3 & 4 & $5,000 \mathrm{~L}_{3}$ C. oncophora $\times 10$ days \\
4 & 4 & $200,000 \mathrm{~L}_{3}$ C. oncophora \\
5 & 4 & $20,000 \mathrm{~L}_{3}$ C. oncophora $\times 10$ days \\
\hline
\end{tabular}


intestine was ligated near the pylorus and the ilio-caecal valve. Starting from the pylorus, the first $3 \mathrm{~m}$ of the small intestine (portion 1) were ligated and removed, leaving a long distal part which was divided into 2 equal parts (portion 2 and portion 3, respectively). The contents from each portion were washed into separate buckets. Washing fluid and the contents were mixed thoroughly and aliquots of $1 / 10$ were drawn and sieved through a $212 \mu \mathrm{m}$ mesh size sieve. The material trapped on the sieve was transferred to a bottle and preserved in iodine solution. To recover the fourth stage larvae, the intestinal mucosa from portion 1 was scraped off and digested in pepsin- $\mathrm{HCl}$ solution $\left(1000 \mathrm{ml} \mathrm{H}_{2} \mathrm{O} ; 150 \mathrm{ml} 1 \mathrm{~N}\right.$ $\mathrm{HCl} ; 8 \mathrm{~g}$ pepsin (1:3000)) in a 'stomacher' at $39^{\circ} \mathrm{C}$ for $0.5 \mathrm{~h}$. The digested suspension was subsequently sieved (screen mesh $36 \mu \mathrm{m}$ ) and the retained material was processed as described above. The worms were counted and examined under a stereo microscope to determine the stage of development.

\section{Other observations and recordings}

The calves were weighed at 2 week intervals in connection with sampling, and they were inspected daily.

\section{Statistical analyses}

Data from the present experiment were analyzed statistically by means of analysis of variance and Student's t-test procedures. Analyses of the faecal egg counts and post mortem worm counts were performed on log-transformed data.

\section{Results}

\section{Clinical observations and performance}

Around 3 weeks after infection, 2 calves from group 4 and 1 calf from each of groups 2 and 5 started to show clinical signs of parasitic enteritis, in that they passed watery stools. At the same time, mild diarrhoea was observed in 1 calf of group 3 . Another calf of group 4 started to show clinical signs during the fourth week of infection. The remaining calves showed no clinical signs throughout the experiment.

All groups exhibited comparable average weight gains over the first 2 weeks of the experiment. However, during the last 2 weeks groups 4 and 5 showed lower gains than the other groups, yet this difference was not statistically different $(\mathrm{p}>0.05)$.

\section{Parasitological findings}

Faecal egg counts. Trichostrongyle eggs were detected in the faeces of 1 calf from group 4 already 2 weeks post infection. Most infected calves passed eggs in the faeces at 3 week p.i. In groups 2 and 3, the highest egg counts were noticed at the termination of the experiment at week 4 p.i. (mean epg of 675 and 388 , respectively) while in group 4 the highest egg counts were noticed at week 3 p.i, i.e. 625 epg. Thus, there was no obvious correlation between faecal egg counts and larval dose or dosing regimen in these groups. The uninfected controls and most calves from group 5 did not excrete eggs.

Serum pepsinogen and albumin levels. Serum pepsinogen levels were within normal ranges (cf. Jørgensen et al. 1976) throughout the experiment. However in the infected groups, the levels rose slightly during the experiment, and on week 2 they differed significantly $(\mathrm{p}<0.01)$ from those of the controls (Table 2). On that occasion, within the same dose level, the trickle infected calves had significantly higher serum pepsinogen levels than the single infected ones $(p<0.05$ and $p<0.01$ for groups 2 vs 3 and groups 4 vs 5 , respectively). Serum albumin levels were within normal ranges and no significant differences were noticed. 
Table 2. Mean serum pepsinogen levels (SD) of the 5 experimental groups of calves.

\begin{tabular}{cccccc}
\hline \multirow{2}{*}{ Group } & \multicolumn{5}{c}{ Week after infection } \\
\cline { 2 - 6 } & 0 & 1 & 2 & 3 & 4 \\
\hline \multirow{2}{*}{1} & 0.3 & 0.6 & $0.3^{\mathrm{a}}$ & 0.4 & 0.5 \\
& $(0.08)$ & $(0.05)$ & $(0.13)$ & $(0.10)$ & $(0.06)$ \\
2 & 0.2 & 0.5 & $0.4^{\mathrm{bc}}$ & 0.4 & 0.5 \\
& $(0.08)$ & $(0.10)$ & $(0.00)$ & $(0.17)$ & $(0.00)$ \\
& 0.2 & 0.4 & $0.6 \mathrm{~b}^{\mathrm{bd}}$ & 0.4 & 0.5 \\
3 & $(0.10)$ & $(0.08)$ & $(0.10)$ & $(0.10)$ & $(0.05)$ \\
& 0.2 & 0.6 & $0.5^{\mathrm{bc}}$ & 0.4 & 0.5 \\
4 & $(0.10)$ & $(0.16)$ & $(0.06)$ & $(0.08)$ & $(0.14)$ \\
& 0.4 & 0.7 & $0.7^{\text {bf }}$ & 0.6 & 0.6 \\
5 & $(0.13)$ & $(0.13)$ & $(0.08)$ & $(0.10)$ & $(0.05)$ \\
\hline
\end{tabular}

Different superscripts in week 2 after infection indicate statistical differences (a and b, e and f: $p<0.01 ; \mathrm{c}$ and d: $\mathrm{p}<0.05)$.

Post mortem worm counts. The post mortem worm findings of the infected groups are presented in Table 3. Although the mean total worm counts and numbers of adult worms were highest in the groups receiving the highest larval doses (groups 4 and 5), the differences were statistically indistinguishable ( $p>0.05$ ) due to large variations within groups. Establishment rates were highest in the groups receiving low doses (groups 2 and 3), but this was as well statistically insignificant ( $\mathrm{p}>0.05)$.

Table 3. Post mortem worm recoveries of the four C. oncophora infected groups (SD).

\begin{tabular}{ccccc}
\hline \multirow{2}{*}{ Group } & \multicolumn{4}{c}{ Cooperia oncophora } \\
\cline { 2 - 5 } & Adults & L4 & Total & $\begin{array}{c}\text { Establishment- } \\
\text { rate (\%) }\end{array}$ \\
\hline 2 & 12,209 & 199 & 12,328 & 24.7 \\
Single, low & $(10,250)$ & $(155)$ & $(10,401)$ & $(20.88)$ \\
3 & 19,814 & 461 & 20,275 & 40.5 \\
Trickle, low & $(1,668)$ & $(449)$ & $(1,497)$ & $(3.03)$ \\
4 & 42,784 & 1,550 & 44,334 & 22.2 \\
Single, high & $(32,015)$ & $(779)$ & $(31,859)$ & $(15.93)$ \\
5 & 26,485 & 3,796 & 30,281 & 15.1 \\
Trickle, high & $(31,911)$ & $(4,822)$ & $(36,399)$ & $(18.20)$ \\
\hline
\end{tabular}


Calves receiving high larval doses harboured significantly higher numbers of fourth stage larvae $(p<0.01)$ than calves receiving lower doses, irrespective of dosing regimen. Also the percentage of fourth stage larvae out of the total worm burden was significantly highest in the groups infected with most larvae $(p<0.01)$. No difference was noticed in the number or percentage of fourth stage larvae (L4) between single or trickle infected groups receiving the same dose of larvae $(\mathrm{p}<0.05)$, although there was a tendency of higher figures as a consequence of trickle infection.

The distribution of worms in the small intestines from the infected groups is presented in Fig. 1. The results show that within the same dose level, there was a tendency of a more even distribution following single infection than following trickle infection, since in the latter groups markedly lower proportions were confined to the distal portions (portion 3 ). The 2 groups receiving the highest number
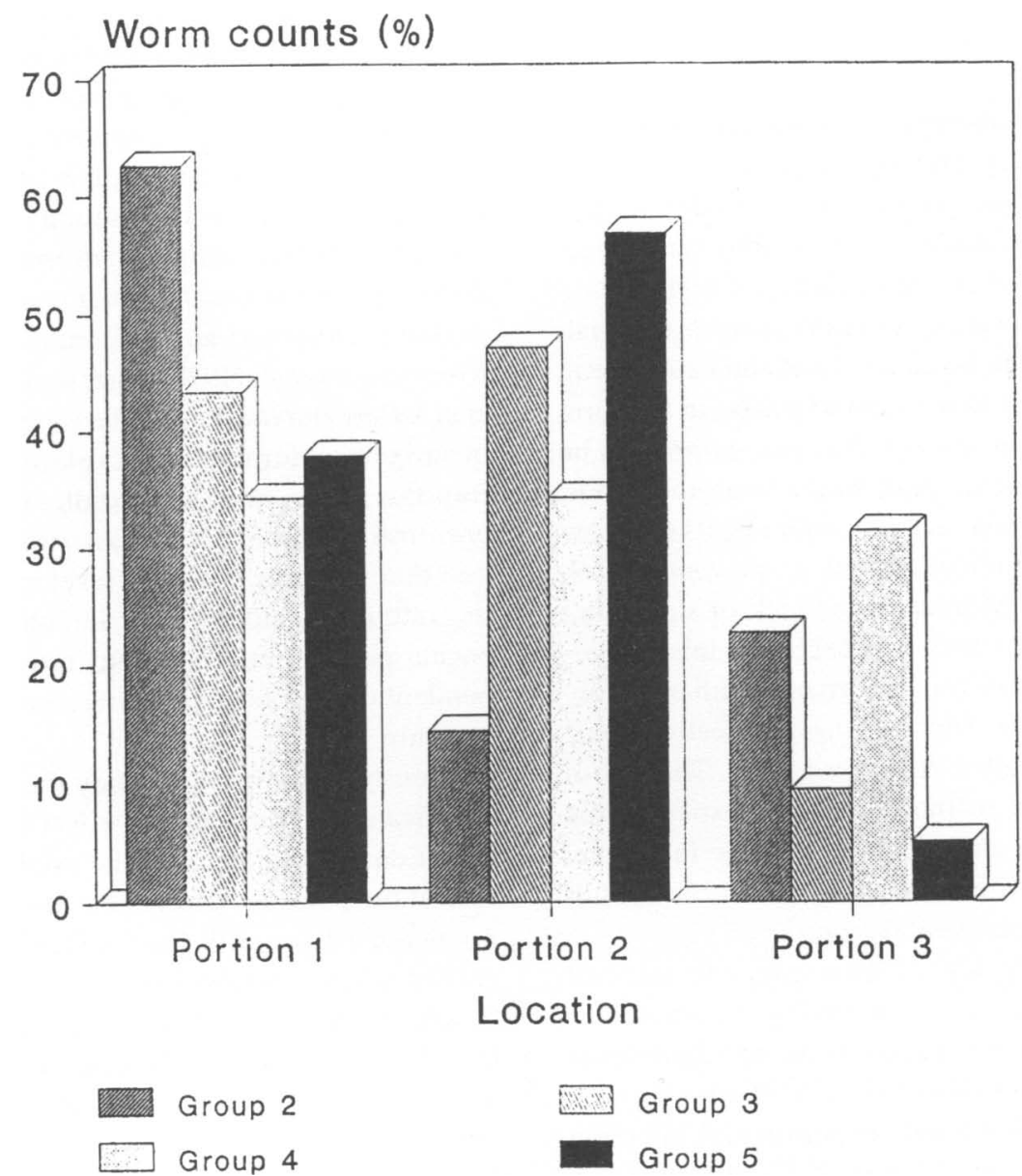

Figure 1. Mean distribution of $C$. oncophora in the small intestines of the infected calves. 
of larvae (groups 4 and 5) tended to have fewer worms in the proximal portion than the other groups. The parasites were most evenly distributed in calves that received a single high dose of larvae (group 4).

\section{Pathological findings}

The small intestines of the infected calves showed some oedema and slight hyperemia. The lesions tended to be less pronounced in the groups which received low numbers of $C$. oncophora, irrespective of dosing regimen.

\section{Discussion}

The observation period in the present experiment (4 weeks) is too short to simulate clinical effects of the parasite which under natural conditions usually occurs as long term infections. However, the tendency of higher clinical effects in group 4 than in group 5, especially during the last 2 weeks of the experiment, may suggest that longer exposure in the form of trickle infections with $C$. oncophora may be less pathogenic than single large infections, which actually is in line with results from experimental infection with $C$. pectinata (Herlich 1967). Moreover, the lack of significant correlation between faecal egg counts and larval dose levels is in accordance with many observations on trichostrongyle infections (e.g. Coop et al. 1979, Henriksen 1981). The lack of significance in the mentioned experimental parameters could be due to large individual variations within the groups, partly as a result of small experimental group size.

The slightly higher establishment rates of worms in the calves receiving the single low larval doses are in accordance with findings of Borgsteede \& Hendriks (1979) who showed that following single experimental infection with 20,000 or 200,000 of $C$. oncophora, a more rapid expulsion of worms occurred in the highly infected group already after 14-28 days. The significantly higher percentage of L4 in calves given many larvae may perhaps reflect an ongoing adult worm expulsion prior to and around the time of slaughter. With regard to the trickle infected groups our findings are roughly in line with results of Dobson et al. (1990a) in sheep, given 3 different levels of trickle infections with $T$. colubriformis, which have shown that establishment of the parasites was highest at the animals receiving the lowest infection rate for the first 4 weeks of the infection, but then fell at a rate similar to that observed for the higher infection rates. A more rapid worm expulsion at a high dose level may be due to development of acquired immunity to the parasite. It has been known for many years that such immunity requires a threshold level of antigenic information produced by the parasite before it can affect the parasite (Dineen et al. 1965), and studies by Kloosterman et al. (1978) suggested that a level of 100,000 larvae may be the threshold level of antigenic information to evoke an immune response to Cooperia spp. Studies on T. colubriformis (Dobson et al. $1990 \mathrm{ab}$ ) in sheep suggest that once the threshold level is exceeded the rate of development of immunity, influencing parasite establishment rates, is independent of dose level but determined by host age only.

Obviously, in the present study there was no significant difference in the effect of the different dosing regimens on the establishment rate of the parasite. Our results are therefore not in accordance with Herlich (1967) who recorded a lower establishment rate in calves, which received $300,000 C$. pectinata divided into 10 consecutive daily doses, compared with that in calves given the same number of larvae as a single infection.

In our experiment the parasites were distributed most evenly throughout the small intes- 
tine in calves which were infected with a single high dose of $C$. oncophora which is in rough correspondence with findings of Borgsteede \& Hendriks (1979). In groups of calves which received $C$. oncophora as trickle infections, only few worms were located distally. This is in accordance with experimental trickle infections earlier described by Coop et al. (1979) and Armour et al. (1987). It is suggested that uptake of high numbers of infective larvae at once may induce migration of the worms to more distal parts of the small intestine possibly due to a 'crowding effect' resulting in unfavourable conditions for establishment of the parasites in the proximal part of the small intestine. A such crowding effect may be less crucial with repeated larval doses.

Although serum pepsinogen and albumin levels of the experimental groups of calves were within normal ranges, the slightly increased serum pepsinogen levels in the infected groups may according to Parkins et al. (1990) be due to damage of gastrin producing cells caused by the presence of $C$. oncophora. Parkins et al. (1990) suggested that an indirect suppressive effect on abomasal acid secretion will in turn reduce the conversion of pepsinogen to pepsin, thus increasing the concentration gradient for pepsinogen between abomasum and plasma, leading to a backflow of pepsinogen to the blood. The higher serum pepsinogen levels in calves receiving trickle infections may perhaps be related to the tendency of higher establishment rate in the proximal parts of the small intestine where gastrin producing cells are predominantly localized.

\section{Acknowledgments}

The authors wish to thank Mr. Niels Midtgaard and Mrs. Karen Madsen for their skillful technical assistance. We are grateful to Pfizer, Agricultural Division, for financial support of this experiment.

\section{References}

Armour J, Bairden K, Holmes PH, Parkins JJ, Ploeger H, Salman SK, Mc Williams PN: Pathophysiological and parasitological studies on Cooperia oncophora infection in calves. Res. vet. Sci. 1987, 42, 373-381.

Borgsteede FHM, Hendriks J: Experimental infections with Cooperia oncophora (Ralliet, 1918) in calves. Results of single infections with two graded dose levels of larvae. Parasitol. 1979, 78, 331-342.

Coop RL, Sykes AR, Angus KW: The pathogenicity of daily intakes of Cooperia oncophora larvae in growing calves. Vet. Parasitol. 1979, 15, 135150.

Dineen JK, Donald AD, Wagland BM, Turner JH: The dynamics of the host-parasite relationship. II. The response of sheep to primary and secondary infection with Nematodirus spathiger. Parasitol. 1965, 55, 163-171.

Dobson RJ, Waller PJ, Donald AD: Population dynamics of Trichostrongylus colubriformis in sheep : The effect of infection rate on the establishment of infective larvae and parasite fecundity. Int. J. Parasitol. 1990a, 20, 347-352.

Dobson RJ, Waller PJ, Donald AD: Population dynamics of Trichostrongylus colubriformis in sheep : The effect of host age on the establishment of infective larvae. Int. J. Parasitol. 1990b, 20, 353-357.

Henriksen S Aa: Infection with Cooperia oncophora in calves. In: Nansen P, Jørgensen RJ, Soulsby EJL (eds): Epidemiology and Control of Nematodiasis in Cattle. Martinus Nijhoff Publishers, London 1981, pp. 547-555.

Henriksen S Aa, Aagaard K: A simple flotation and McMaster method. Nord. vet. Med. 1976, 28, 392-397.

Herlich $H$ : The effects of the intestinal worms, Cooperia pectinata and Cooperia oncophora, on experimentally infected calves. Amer. J. vet. Res. $1965,26,1032-1036$.

Herlich $H$ : Effects of Cooperia pectinata on calves: Two levels of repeated oral inoculation. Amer. J. vet. Res. 1967, 28, 71-77.

Jørgensen RJ, Henriksen S Aa, Sejrsen K, Nansen P: The serum pepsinogen analysis and its relation to bovine ostertagiasis. Nord. vet. Med. 1976, 28, 210-126.

Kloosterman A, Albers GAA, van den Brink R: Genetic variation among calves in resistance to 
nematode parasites. Vet. Parasitol. 1978, 4, 353368.

Nisbet J, Jarvis A, Feton A: Measurement of human serum albumin with bromcresol green. A simultaneous comparison of two methods on SMA 12/60. Clin. Chim. Acta. 1973, 45, 189-191.

Parkins JJ, Taylor L M, Holmes P H, Bairden K, Salman $S K$, Armour J: Pathophysiological and parasitological studies on a concurrent infection of Ostertagia ostertagi and Cooperia oncophora in calves. Res. vet. Sci. 1990, 48, 201-208.

Ross J G, Purcell D A, Dow C, Todd J R: Experimental infection of calves with Trichostrongylus axei: The course of development of infection and lesions in low level infections. Res. vet. Sci. 8, 201-206.

\section{Sammendrag}

Eksperimentel infektion af kalve med Cooperia oncophora: En unders $\varnothing$ gelse til belysning af to forskellige dosisniveauer og to forskellige infektionsprocedurer.

Konsekvenserne af 2 forskellige dosisniveauer og 2 forskelligé infektionsprocedurer med Cooperia oncophora i kalve blev unders $\varnothing$ gt. Fire grupper, bestående af hver 4 kalve, blev eksperimentelt inficeret med hhv. 50.000 og 200.000 C. oncophora lar- ver $\left(L_{3}\right)$, doseret enten på én gang eller som "trickle"-infektioner. En femte gruppe fungerede som uinficerede kontroldyr. Dyrene blev aflivet og undersøgt 4 uger efter infektionernes start.

Hos grupperne, som modtog de højeste larvedoser, observeredes lette til moderate symptomer på parasitær gastroenteritis, men dyrenes tilvækst adskilte sig dog ikke signifikant fra kontroldyrenes. De inficerede gruppers serum pepsinogen koncentrationer lå hele tiden i normalområdet, men steg dog noget, og fra dag 14 var de signifikant højere end $i$ kontrolgruppen. Tilmed udviste de "trickle"-inficerede grupper signifikant højere koncentrationer end de éngangsdoserede. Ved intet tilfælde observeredes hypoalbuminæmi.

De inficerede grupper adskilte sig ikke fra hinanden, hverken hvad angik det totale antal parasitter eller det totale antal adulte parasitter, men de 2 grupper, som blev doseret med flest larver, viste sig at have flere 4. stadium larver end de lavt doserede grupper, både udtrykt som absolut antal og som procentvis andel. Inden for samme infektionsniveau, sås hos de éngangsinficerede en tendens til en mere jævn fordeling af parasitterne i tyndtarmen hos de "trickle"inficerede.

Resultaterne viser, at såvel dosisniveau som infektionsprocedure får indflydelse på C.oncophora's patogenitet, og i nogen grad også på fordelingen af parasitten i tyndtarmen.

(Received April 9, 1992; accepted May 22, 1992).

Reprints may be requested from: Peter Nansen, Section of Parasitology, Department of Veterinary Microbiology, Royal Veterinary and Agricultural University, 13 Bülowsvej, DK - 1870 Frederiksberg C, Denmark. 